\title{
Unit Roots and Co-Integration Tests: the Effects of Consumer Price Index (CPI) on Non-Performing Loans (NPL) in the Banking Sector in Malaysia
}

\author{
Mohd Yaziz Bin Mohd Isa and Zulkifflee Bin Mohamed \\ Universiti Tun Abdul Razak (UNIRAZAK), Kuala Lumpur, Malaysia \\ Email: mohd_yaziz@unirazak.edu.my
}

\begin{abstract}
The purpose of this study is to examine whether there is any genuine long run relationship between Consumer Price Index (CPI) and Non-Performing Loans (NPL). Using the logarithmic values of Consumer Price Index (CPI) inflation and Non-Performing Loans (NPL), different methodologies are employed in the analysis so that the robustness of unit roots and cointegration results is guaranteed. Based on the results, we consistently do not observe any genuine long run relationship between the two variables.
\end{abstract}

Keywords: Unit root tests, co-integration tests, non-performing loans, consumer price index (CPI)

\section{Introduction}

The Malaysian Law Journal interprets "Non-Performing Loan (NPL)", as a loan, given to a person by a licensed institution, which has been in arrears for a period of times as may be determined by the licensed institution. According to Amirhossein and Soon-Yau (2013) banks in Malaysia classify nonperforming loans into four classes: bad loan, doubtful loan, substandard loan and special-mentioned. Further, the classification is based on the bank's re-scheduled loan repayment timetable and its perceived probability of loan repayment, the authors add. The authors carried out a number of investigations into the effects of Audit Expectation Gap (AEG) on bank officer's loan quality decision. The authors point out non-performing loans may be reduced if bank officers enhance their understanding of the auditor's responsibilities. The findings might have been far more convincing if they had included all banks in Malaysia in their sample. In a study on non-performing loan of Vietnamese banks by Delpachitra and Dai Van (2015), the authors use non-performing loan rate as a proxy for a default probability rate. By comparison in a study on loan loss provisioning practices of Malaysian banks Mohd Isa, Yap and Yong (2013) indicate the expected loss approach capture the amount of expected loss of non-performing loans more timely. Central to the entire discipline of non-performing loan is that it is a factor in the loan loss provisioning process, the authors conclude. In a recent study on the influence of institutional investors on bank loans, Huajing and Yili (2016) discovered shareholder controls are negatively related to loan costs. The authors measure the cost of bank loans through loan spreads, the number of collateral requirements and prepayment covenants. The authors find institutional holdings are negatively related to the cost of bank loans. The findings would have been far more useful if the authors had included the cost of non-performing loans.

The Consumer Price Index (CPI) measures the average change in the price paid by consumers for consumer goods and services. The index provides information about average price changes reflecting value of the Ringgit to find its purchasing power. In this regards, the purchasing power of the consumer's Ringgit measures the change in the value to the consumers of goods and services that a Ringgit will buy at different times. As prices increase, the purchasing power of the consumer's Ringgit declines. With changing financial obligations of households these days, it is becoming increasingly difficult to ignore the importance of proper debt management. According to Bank Negara Malaysia's Annual Report, the inflation rate as measured by the average change in the CPI is an approximation of the rate of increase in the cost of living (Bank Negara Malaysia 2016, pp. 64). 
In a recent study by Yao and Oppewap (2016) on consumers response to unit pricing (the display of an item's price per unit) the authors report that it shifts consumer choices towards the lower unit priced options. Interestingly, the study also finds the moderating role of time pressure. It results in greater responsiveness, the authors conclude.

More recently, a study based on a sample of 22 banks in Ghana, Laryea, Gyamfi and Alu (2016) find that inflation is positively associated to non-performing loans (NPL). The authors further discover that the level of non-performing loans affects profitability of the banks. It is becoming increasingly difficult to ignore the risks pose to the banks because of loans default. As economic conditions do contribute to the likelihood of being delinquent on debt, in a study by Jing Jian and Rui (2014) on patterns of loan delinquency of bank consumers, the findings suggest that family should adjust their spending downward in uncertain economic conditions. This is to reduce the likelihood of being delinquent in debt payment. Not only profitability but also bank's success are negatively affected by non-performing loans, the authors argue. McCloud and Dwyer (2011), as cited in Jing Jian and Rui (2014) attribute the likelihood of a household's debt default to income disruption. In contrast in the case of Vietnamese banks, Sarath and Pham (2015) reveal that bank's non-performing loans level does not significantly affect loan supply. The authors subscribed to the belief it is because of the divergence in lending practice between private and public banks.

This paper contributes to the existing literature on the study on delinquent loans in two ways. Firstly, it provides a new channel through which loans delinquent due to CPI. Against the rise in household debt in Malaysia where its ratio to gross domestic product (GDP) increased to $89.1 \%$ in 2015 from $86.8 \%$ the previous year, to examine on the relationship between non-performing loans (NPL) and consumer price index (CPI) is timely indeed. Will higher indebtedness effects on the level of nonperforming loans? As previously argued, CPI is different from GDP, and this study attempts to fill in the gap in the research on CPI on delinquent loans. As the CPI reflects the value of the Ringgit, its depreciating trends against most major and regional currencies reflect the declining purchasing power. In Malaysia, the Ringgit has depreciated by 3\% against the US dollar in the third quarter 2016 (Bank Negara Malaysia (BNM) Economic and Financial Developments in Malaysia in the third quarter of 2016). Esther, Mathew and Angela (2016) in a study on the effect of non-performing loan on bank profitability use the Consumer Price Index (CPI) as an indicator of annual inflation. In recent years, there have been increasing trends in national average inflation rate. In 2017, increase in pump prices and several price adjustments - constituting about $8 \%$ of CPI index components - have been identified as major contributing factors for possible increase in inflation rate by between $2.5 \%$ and $2.8 \%$. ("Inflation in 2017 will be manageable", 2016).

The remainder of the paper is organized as follows. Section 2 discusses the model specifications. Section 3 describes the data statistics. Section 4 reports the empirical results and section 5 provides concluding remarks.

\section{Model Specification}

In order to examine the long run relationship between Consumer Price Index (CPI) and NonPerforming Loans (NPL) we consider the following model where the Non-Performing Loans (NPL) is regressed on the Consumer Price Index (CPI).

$\log \mathrm{NPL}=\mathrm{f}\left(\log \mathrm{CPI} \mathrm{t}_{\mathrm{t}}\right)+$ Error term, where

Log NPL is Non Performing Loans (in natural log), LnNPL ${ }_{t}$

Log CPI is Consumer Price Index (CPI) (in natural log), LnCPI

So, we have $\operatorname{LnNPL}_{\mathrm{t}}=B_{0}+B_{1} \mathrm{LnCPI}_{\mathrm{t}}+\varepsilon_{\mathrm{t}}$

In compliance with the assumptions of the classical linear regression model (CLRM);

$\checkmark$ the regression model is linear in coefficients

$\checkmark$ is correctly specified

$\checkmark$ has an error term (disturbance term), $\varepsilon_{\mathrm{t}}$

$\checkmark$ explanatory variable (NPL) is uncorrelated with the error term $\left(\varepsilon_{t}\right)$

$\checkmark$ no multi-collinearity (however in this study there is only one independent variable, NPL)

$\checkmark \quad$ "n" (sample size $=45$ observations i.e. monthly from January 2013 to September 2016 is $>$ " $\mathrm{k}$ " (number of parameters $=3$ ), to ensure degree of freedom is "+". 
Table 1. Model specifications: LnCPI level data

\begin{tabular}{ll}
\hline Model LnCPI level data & To include in equation \\
\hline$\Delta\left(\mathrm{LnCPI}_{\mathrm{t}}\right)=B_{0}+B_{1} \mathrm{LnCPI}_{\mathrm{t}-1}+\varepsilon_{\mathrm{t}}$ & Intercept \\
$\Delta\left(\mathrm{LnCPI}_{\mathrm{t}}\right)=B_{0}+\mathrm{B}_{1}$ Trend $+B_{2} \mathrm{LnCPI}_{\mathrm{t}-1}+\varepsilon_{\mathrm{t}}$ & Trend and Intercept \\
$\Delta\left(\mathrm{LnCPI}_{\mathrm{t}}\right)=B_{1} \mathrm{LnCPI}_{\mathrm{t}-1}+\varepsilon_{\mathrm{t}}$ & No trend, no intercept \\
\hline
\end{tabular}

\section{$3 \quad$ Data Statistics}

The monthly data for this study on Consumer Price Index (CPI) and Non-Performing Loans (NPL) are obtained from the Bank Negara Malaysia (BNM) database. The data starts from January 2013 until September 2016 totalling 45 observations. Therefore, our study is more current in terms of time scopes making it more pertinent. The data on non-performing loan rates are reported as the average of the whole banking industry rather than as the rates of individual banks. Given that the banking industry in Malaysia is not monopolistic in which banks report about the same NPL rates, specifying an empirical model based on 45 observations seems acceptable for a robust time series analysis.

For CPI, since the cross-sectional data with delinquency across multiple CPI categories are limited or unavailable, this study also uses time series data on CPI to depict an overall aggregate picture of nonperforming loans due to changes in Consumer Price Index (CPI).

\section{Tests Results}

Graphically, we noticed the pattern of time series in the line graphs of LnNPL and LnCPI as follows. The graphs 1 and 2 below exhibit plots of stochastic trends non-stationary models.

LNNPL

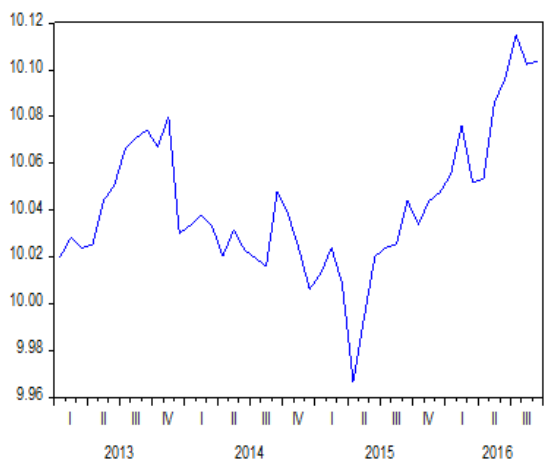

Graph 1. LNNPL
LNCPI

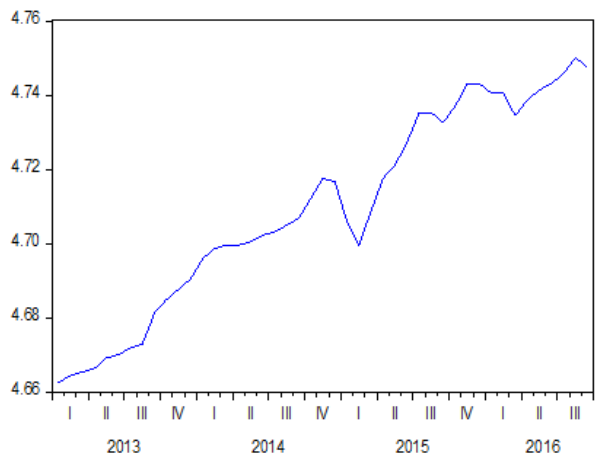

Graph 2. LNCPI

In order to deal with the stochastic non-stationary series, we induced stationarity by "differencing" as in Table 2 below. This is required before analysis the data has to be stationary for shocks to have permanent effects rather than transitory (effects).

Table 2. Model specifications: LnNPL first difference

\begin{tabular}{ll}
\hline Model LnNPL first difference & To include in equation \\
\hline$\Delta\left(\operatorname{LnNPL}_{\mathrm{t}}, 2\right)=B_{0}+\Delta B_{1} \mathrm{LnNPL}_{\mathrm{t}-1}+\varepsilon_{\mathrm{t}}$ & Intercept \\
$\Delta\left(\mathrm{LnNPL}_{\mathrm{t}}, 2\right)=B_{0}+\mathrm{B}_{1}$Trend $+\Delta B_{2} \mathrm{LnNPL}_{\mathrm{t}-1}+\varepsilon_{\mathrm{t}}$ & Trend and Intercept \\
$\Delta\left(\right.$ LnNPL $\left._{\mathrm{t}}, 2\right)=\Delta B_{1} \mathrm{LnNPL}_{\mathrm{t}-1}+\varepsilon_{\mathrm{t}}$ & No trend, no intercept \\
\hline
\end{tabular}




\subsection{Tests for Unit Roots}

As a pre-test prior to estimation and inference of the long term relationship between the two variables, we tested the existence of unit-root and whether the data is stationary. For this purpose, the following tests are conducted as in table 3 below:

Table 3. Tests available

\begin{tabular}{ll}
\hline Unit root tests & Stationary test \\
\hline Augmented Dickey-Fuller (ADF) & Kwiatkowski, Phillips, Schmidt and Skin (KPSS) \\
Phillips-Perron (PP) & \\
\hline
\end{tabular}

(i) Augmented Dickey-Fuller (ADF) test

We conducted unit root tests for both variables (LnCPI and LnNPL) firstly using the Augmented Dickey-Fuller (ADF) method. The null hypothesis for the ADV model is the data has unit root (i.e. the data is non-stationary).

The results in levels indicate that the data contains unit root (i.e. the data is non-stationary). So we proceed to first difference as in table 4 below.

Table 4. ADF unit root test results of logs of CPI and NPL in levels and differences.

\begin{tabular}{|c|c|c|c|c|}
\hline \multirow{3}{*}{$\frac{\text {.Test }}{\text { Variable }}$} & \multicolumn{4}{|c|}{$\mathrm{ADF}$} \\
\hline & \multicolumn{2}{|c|}{ In level, LnCPI } & \multicolumn{2}{|c|}{ In level, LnNPL } \\
\hline & t-Statistic & p-value & t-Statistic & p-value \\
\hline Intercept & $-1.256(9)$ & 0.641 & $-1.398(9)$ & 0.575 \\
\hline Trend \& Intercept & $-3.358(9)$ & 0.071 & $-1.619(9)$ & 0.769 \\
\hline \multirow[t]{3}{*}{ None } & $2.880(9)$ & 0.999 & $0.740(9)$ & 0.871 \\
\hline & \multicolumn{2}{|c|}{ In difference LnCPI } & \multicolumn{2}{|c|}{ In difference LnNPL } \\
\hline & t-statistics & p-value & t-Statistic & p-value \\
\hline Intercept & $-5.605(9)$ & $0.000^{\mathrm{b}}$ & $-7.021(9)$ & $0.000^{\mathrm{b}}$ \\
\hline Trend \& Intercept & $-5.642(9)$ & $0.000^{\mathrm{b}}$ & $-4.496(9)$ & $0.001^{\mathrm{b}}$ \\
\hline None & $-4.417(9)$ & $0.000^{\mathrm{b}}$ & $-7.023(9)$ & $0.000^{\mathrm{b}}$ \\
\hline
\end{tabular}

Figure in parenthesis represents optimum lag length selected based on Akaike Info Criterion

The interpretation is that in level data, the p-values are higher than specified significance levels 0.05 $(5 \%)$ and $0.01(1 \%)$. So we failed to reject the null hypothesis in both cases, at $5 \%$ level critical value and at $1 \%$ level critical value. Even at $10 \%(0.1)$ level critical value we failed to reject the null hypothesis. Besides, the t-Statistic is 1.256 (in absolute value) which is less than 2.604 (in absolute value) at the $10 \%$ level critical value, the weak significance. Therefore, the level data has a unit root or the series is not-stationary in level.

The data becomes stationary in first difference. In the first difference, we rejected the null hypothesis at $1 \%$ level critical values as the p-values (0.000) are less than 0.01 (1\%) level critical values.

(ii) Kwiatkowski, Phillips, Schmidt and Skin (KPSS) test

Another complementing test to the ADF test is the Kwiatkowski, Phillips, Schmidt and Skin (KPSS) in which case the null hypothesis is trend-stationary. This is against the alternative hypothesis, the presence of a unit root. It is important to note however in the case of KPSS test, the absence of a unit root is not a proof of data stationary, but of trend-stationary. It is possible the data is non-stationary, have no unit root but is trend-stationary. 
Table 5. Kwiatkowski, Phillips, Schmidt and Skin (KPSS) unit root test results of logs of CPI and NPL in levels and differences

\begin{tabular}{|c|c|c|c|c|}
\hline \multirow{3}{*}{$\begin{array}{r}\text { Test } \\
\text { Variable }\end{array}$} & \multicolumn{4}{|c|}{ KPSS } \\
\hline & \multicolumn{2}{|c|}{ In level, LnCPI } & \multicolumn{2}{|c|}{ In level, LnNPL } \\
\hline & LM-Stat & CV 5\% & LM-Stat & CV $5 \%$ \\
\hline Intercept & 0.839 & 0.463 & 0.236 & 0.463 \\
\hline \multirow[t]{3}{*}{ Trend \& Intercept } & 0.094 & 0.146 & 0.171 & 0.146 \\
\hline & \multicolumn{2}{|c|}{ In difference LnCPI } & \multicolumn{2}{|c|}{ In difference LnNPL } \\
\hline & LM-Stat & CV 5\% & LM-Stat & $\mathrm{CV} 5 \%$ \\
\hline Intercept & 0.137 & $0.463^{\mathrm{a}}$ & 0.181 & $0.463^{\mathrm{a}}$ \\
\hline Trend \& Intercept & 0.088 & 0.146 & 0.138 & 0.146 \\
\hline
\end{tabular}

Figure in parenthesis represents optimum lag length selected based on Akaike Info Criterion

For the data in first-difference since the estimated test-statistic 0.137 is less than 0.463 the critical value at $5 \%$, we cannot reject the null hypothesis the data is trend-stationary. There is no evidence that the data in first-difference is not trend-stationary.

(iii) Phillips-Perron (PP) test

Besides ADF and KPSS tests, another complementing test is the Phillips-Perron (PP) test. In the case of the Philips-Perron (PP) test, it is a unit root test to test the null hypothesis that the series integrated of order 1 . The PP test tests the generating data might have a higher order of autocorrelation than is admitted in the equation resulting $\mathrm{Y}_{\mathrm{t}-1}$ endogeneous and therefore invalidating the ADF t-test as in table 6 below.

Table 6. Phillips-Perron (PP) unit root test results of logs of CPI and NPL in levels and differences

\begin{tabular}{l|l|l|l|l}
\hline \multirow{2}{*}{ Test } & \multicolumn{4}{c}{ Phillips-Perron (PP) } \\
\hline \multirow{2}{*}{ Variable } & \multicolumn{2}{|c}{ In level, LnCPI } & \multicolumn{2}{c}{ In level, LnNPL } \\
\cline { 2 - 5 } & Adj. T-Statistic & p-value & Adj. T-Statistic & p-value \\
\hline Intercept & -1.161 & 0.683 & -1.296 & 0.623 \\
\hline Trend \& Intercept & -2.365 & 0.392 & -1.518 & 0.808 \\
\hline None & 4.151 & 1.000 & 0.920 & 0.902 \\
\hline \multicolumn{4}{|c}{} \\
\hline \multirow{4}{*}{ In difference LnCPI } & \multicolumn{1}{c}{ In difference LnNPL } \\
\cline { 2 - 5 } & Adj. T-statistics & p-value & Adj. T-Statistic & p-value \\
\hline Intercept & -0.474 & 0.000 & -7.124 & 0.000 \\
\hline Trend \& Intercept & -5.589 & 0.000 & -7.520 & 0.000 \\
\hline None & -3.922 & 0.000 & -7.095 & 0.000 \\
\hline
\end{tabular}

Source: Own elaboration

${ }^{a}$ Null hypothesis rejected at $5 \%$.

${ }^{\mathrm{b}}$ Null hypothesis rejected at $1 \%$.

Figure in parenthesis represents optimum lag length selected based on Akaike Info Criterion. The results of unit root and stationary tests using the ADF, KPSS and PP tests taken in logs for the two variables CPI and NPL in Tables 2, 3 and 4 above show the variables are integrated of first order (which technically means difference of once or integrated of order one series I(1)).

Returning to estimate stationary test equations for the three tests, we find the following results as in table 7 . 
Table 7. Test equations

\begin{tabular}{|c|c|c|}
\hline No. & Variable & ADF, KPSS and PP test equations ${ }^{a}$ \\
\hline 1.0 & $\ln \mathrm{CPI}$ & $\begin{array}{l}\text { Constant is significant, so need to include the constant term. } \\
\text { Trend is not significant so does not need to include the trend term. }\end{array}$ \\
\hline 2.0 & $\operatorname{lnNPL}$ & $\begin{array}{l}\text { Constant is not significant, so does not need to include the constant term. } \\
\text { Trend is not significant, so does not need to include the trend term }\end{array}$ \\
\hline
\end{tabular}

a Model is stationary

As all the above tests (unit root, stationary and test equation) yield similar results implying the data is stationary in first differences our confidence in their estimates increases, and robustness of the estimates is guaranteed.

The graphs below exhibit plots of stationary models of first differences for LnCPI and LnNPL. Interestingly Noghondari and Fong (2013) state that Non Performing Loans may be reduced through recruiting bank officers with the right accounting skills.

DLNNPL

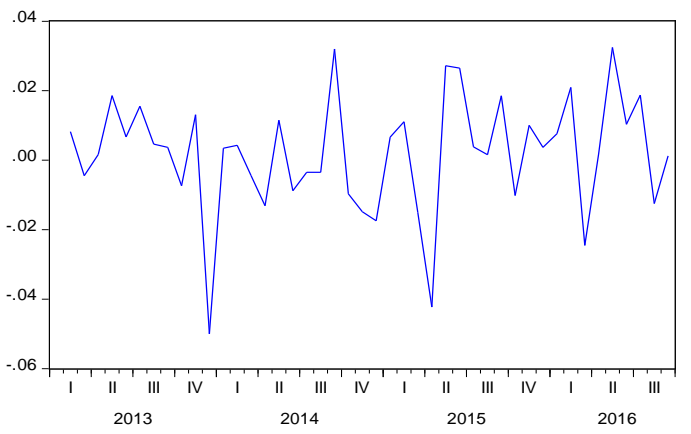

Graph 3. DLNPL
DLNCPI

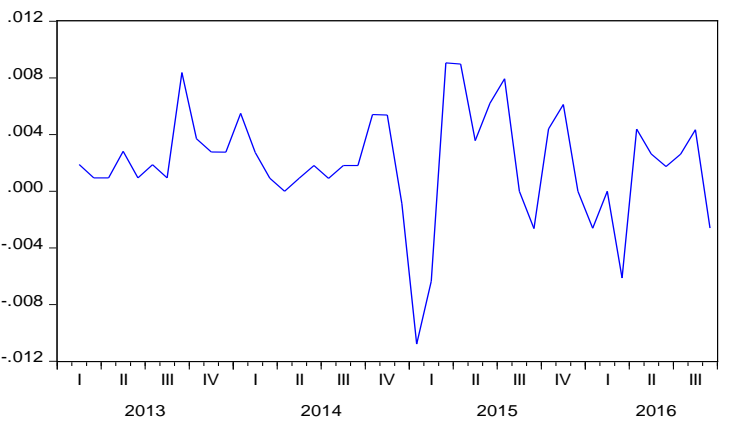

Graph 4. DLNCPI

\subsection{Tests for Co-integration}

Next step is to test for a genuine and an equilibrium long-run relationship between CPI and NPL, i.e., to test whether co-integration or "co-movement" between the two variables exists. In other words, we are also to test for the presence of "spurious" regression problems in the regression. A spurious model is not desirable or acceptable.

The graphs below detect the regression suffers from spurious regression problem suggesting relationships between $\mathrm{npl}$ and cpi when there are none. Also because the series are $\mathrm{I}(1)$ we cannot rely on the series. It might be spurious regression. It can be observed from the graphs, the gap between npl and cpi over time becomes wider indicating there is no equilibrium relationship between npl and cpi.

$\mathrm{np}$

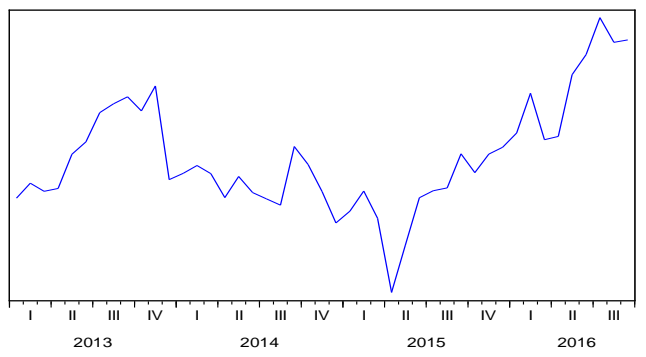

Graph 5. npl s

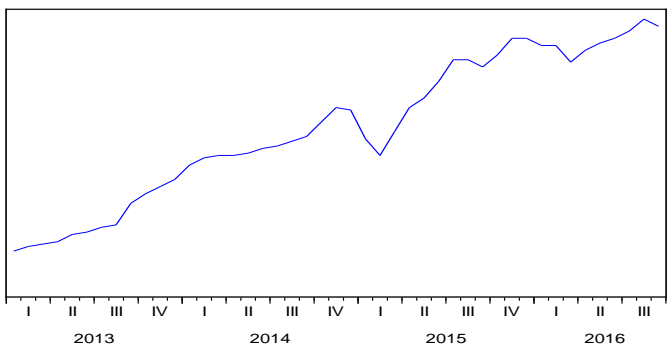

Graph 6. cpi 
The estimate of the long-run regression using Ordinary Least Squares (OLS) is as tabulated below in Table 8 .

Table 8. Ordinary Least Square (OLS)

Dependent Variable: NPL

Method: Least Squares

Sample: 2013M01 2016M09

Included observations: 45

\begin{tabular}{|c|c|c|c|c|}
\hline Variable & Coefficient & Std. Error & t-Statistic & Prob. \\
\hline $\mathrm{CPI}$ & 66.23250 & 34.15472 & 1.939190 & 0.0591 \\
\hline $\mathrm{C}$ & 15629.88 & 3794.362 & 4.119238 & 0.0002 \\
\hline R-squared & 0.080420 & \multicolumn{2}{|c|}{ Mean dependent var } & 22985.22 \\
\hline Adjusted R-squared & 0.059034 & \multicolumn{2}{|c|}{ S.D. dependent var } & 704.1189 \\
\hline S.E. of regression & 683.0193 & \multicolumn{2}{|c|}{ Akaike info criterion } & 15.93435 \\
\hline Sum squared resid & 20060161 & \multicolumn{2}{|c|}{ Schwarz criterion } & 16.01465 \\
\hline Log likelihood & -356.5229 & \multicolumn{2}{|c|}{ Hannan-Quinn criter. } & 15.96428 \\
\hline F-statistic & 3.760458 & \multirow{2}{*}{\multicolumn{2}{|c|}{ Durbin-Watson stat }} & 0.332259 \\
\hline Prob(F-statistic) & 0.059058 & & & \\
\hline
\end{tabular}

Note: To test for co-integration, the NPL and CPI series are assumed to be I(1), that is they require a differencing at least once to become stationary; and not $\mathrm{I}(0)$; otherwise we cannot use this co-integration procedure. We have tested and discovered that after first difference the two series become stationary, therefore they are I(1) Also, even if both series are I(1); the regression process itself - in combination - in the long run become stationary $\mathrm{I}(0)$; they become stationary as the model itself adjust the "noises" or the "shocks". So, the series become cointegrated.

There are 2 popular approaches for testing for co-integration:

1) The single equation method of residual-based test: the Engle-Granger co-integration test and

2 ) The system equation method: the Johansen and Juselius co-integration test

3 ) The single equation method of residual-based test: the Engle-Granger co-integration test

The Engle-Granger 2-steps residual-based test of co-integration is the unit roots test applied to residuals obtained from Ordinary Least Squares (OLS) estimation of the long-run regression (in step 1 above).

The result of step 2 is as tabulated below in Table 9.

From the above table our residuals equation = NPL - 66.2325 CPI -15629.88 ("the constant"). In this test, instead of using the standard critical values, we use the Engle-Granger test critical values at $1 \%$ of -3.89644 , at $5 \%$ of -3.33613 and at $10 \%$ of -3.04445 (MacKinnon, 2010). Since the estimated t-statistic of -1.612173 is smaller than the critical value of -3.89644 at $1 \%$; we cannot reject null hypothesis of unit root in the residual series.

The Engle-Granger tau-statistic (t-statistic) and normalized auto-correlation coefficient (z-statistic) both cannot reject the null hypothesis that there is a unit root in the residual series. We fail to reject the null hypothesis of no co-integration in the unit root of the residuals between npl and cpi at $5 \%$ level too. In addition, the tau-statistic (t-statistic) fails to reject at a $10 \%$ significance level.

The evidence clearly suggests that npl and cpi are not co-integrated. The two series do not have long run relationship or equilibrium between them. The possibly d.f. corrected coefficient standard error for $\mathrm{npl}$ is 0.088423 and $\mathrm{cpi}$ is 0.036054 . The squared standard error of the regression is 146169.0 for $\mathrm{npl}$ and 0.470006 for cpi. Next is the Johansen and Juselius co-integration test as in table 10 below.

There are limitations of this study that should be acknowledged. Future research may need to use cross-sectional data sets to examine delinquency across multiple CPI categories. In addition, as has been suggested that theoretically indicators of inflation may include not only consumer prices proxy by CPI, but also economic growth and trade openness (Aviral, Muhammad and Faridul, 2013). This would provide more insight into future study. Future study should also be encouraged to use data from other countries to identify commonalities and differences of consumer delinquent behaviours at the international level. 
Table 9. the Engle-Granger test results

Series: NPL CPI

Sample: 2013M01 2016M09

Included observations: 45

Null hypothesis: Series are not cointegrated

Cointegrating equation deterministics: $\mathrm{C}$

Automatic lags specification based on Schwarz criterion (maxlag=9)

\begin{tabular}{c|c|c|c|c}
\hline Dependent & tau-statistic & Prob.* $^{*}$ & z-statistic & Prob.* $^{*}$ \\
\hline NPL & -1.612173 & 0.7185 & -6.272340 & 0.6064 \\
\hline CPI & -1.357781 & 0.8139 & -2.153966 & 0.9247 \\
\hline
\end{tabular}

*MacKinnon (1996) p-values.

Intermediate Results:

Rho - 1

Rho S.E

Residual variance

Long-run residual variance

Number of lags

Number of observations

Number of stochastic trends**

\begin{tabular}{|c|c|c|}
\hline \multicolumn{2}{l|}{} & CPI \\
\hline & NPL & -0.048954 \\
\hline & 0.142553 & 0.036054 \\
\hline & 146169.0 & 0.470006 \\
\hline 146169.0 & 0.470006 \\
\hline 0 & 0 \\
\hline & 44 & 44 \\
\hline
\end{tabular}

**Number of stochastic trends in asymptotic distribution

Table 10. Johansen and Juselius co-integration test

Sample (adjusted): 2013M03 2016M09

Included observations: 43 after adjustments

Trend assumption: Linear deterministic trend

Series: NPL CPI

Lags interval (in first differences): 1 to 1

Unrestricted Cointegration Rank Test (Trace)

\begin{tabular}{c|c|c|c|c}
\hline Hypothesized & & Trace & $\mathbf{0 . 0 5}$ & \\
\hline No. of CE(s) & Eigenvalue & Statistic & Critical Value & Prob.** $^{* *}$ \\
\hline None & 0.065366 & 3.884777 & 15.49471 & 0.9126 \\
\hline At most 1 & 0.022487 & 0.977958 & 3.841466 & 0.3227 \\
\hline
\end{tabular}

Trace test indicates no cointegration at the 0.05 level

$*$ denotes rejection of the hypothesis at the 0.05 level

**MacKinnon-Haug-Michelis (1999) p-values

Unrestricted Cointegration Rank Test (Maximum Eigenvalue)

\begin{tabular}{c|c|c|c|c}
\hline Hypothesized & & Max-Eigen & $\mathbf{0 . 0 5}$ & \\
\hline No. of CE(s) & Eigenvalue & Statistic & Critical Value & Prob. $^{* *}$ \\
\hline None & 0.065366 & 2.906820 & 14.26460 & 0.9528 \\
\hline At most 1 & 0.022487 & 0.977958 & 3.841466 & 0.3227 \\
\hline
\end{tabular}

Max-eigenvalue test indicates no cointegration at the 0.05 level

* denotes rejection of the hypothesis at the 0.05 level

**MacKinnon-Haug-Michelis (1999) p-values 


\section{Conclusion}

Using monthly data from January 2013 to September 2016 totalling 45 observations, the purpose of this paper is to examine whether there is a genuine long run relationship between Consumer Price Index (CPI) and Non-Performing Loans (NPL). A number of tests are carried-out for the purpose including unit roots and co-integration tests. Based on the results, we consistently do not observe any genuine long run relationship between the two variables. Our finding supports Esther, Mathew and Angela (2016) conclusion that inflation - as measured by CPI - is not significant in determining non-performing loans although it is positively related.

\section{References}

1. Amirhossein, Noghondari Taebi and Soon-Yau, Foong (2013), "Antecedents and consequences of audit expectation gaps. Evidence from the banking sector in Malaysia", Managerial Auditing Journal, Vol. 28, Iss. 5, pp.384-406

2. Aviral, Kumar Tiwari, Muhammad, Shahbaz and Faridul, Islam (2013), "Does financial development increases rural-urban income inequality?: Co-integration analysis in the case of Indian economy", International Journal of Social Economics, Vol. 40, No. 2, pp. 161-168

3. Bank Negara Malaysia (2016), Annual Report 2015 "Box Article: Inflation and the Cost of Living". Retrieved from BNM website: http://www.bnm.gov.my/files/publication/ar/en/2015/cp01_003_box.pdf

4. Bank Negara Malaysia (2016), Economic and Financial Developments in the Malaysian Economy in the Third Quarter of 2016. Retrieved from BNM website: http://www.bnm.gov.my/files/publication/qb/2016/Q3_en.pdf

5. Delpachitra, Sarath and Dai Van, Pham (2015), "The determinants of Vietnamese banks' lending behaviour: a theoretical model and empirical evidence", Journal of Economic Studies", Vol. 42 Iss. 5 pp. 861-877

6. Ester, Laryea, Mathew, Ntow-Gyamfi and Angela Azumah Ali (2016), "Non-performing loans and bank profitability: evidence from an emerging market", African Journal of Economic and Management Studies, Vol. 7 , Iss. 4, pp. 462-481

7. Kee, Eng Yoke (2016), Time Series Econometrics using EViews 9.0 19-20 November, 2016 organised by University of Malaya Malaysian Centre of Regulatory Studies (UMCoRS), pp. 1-38

8. Huajing, Hu and Yili, Lian (2016), "Institutional investors and the cost of bank loans", Managerial Finance, Vol. 42 Iss. 6, pp. 569-584

9. "Inflation in 2017 will be manageable" (2016, December, 30), The Sun, pp. 14.

10. Jing Jian, Xiao and Rui, Yao (2014), "Consumer debt delinquency by family lifecycle categories", International Journal of Bank Marketing, Vol. 32, Iss. 1, pp. 43-59

11. McCloud, L. and Dwyer, R.E. (2011), "The fragile American: hardship and financial troubles in the $21^{\text {st }}$ century", Sociological Quarterly, Vol. 52, No. 1, pp. 13-35

12. MacKinnon, James G. (2010), "Critical Values for Co-integration Tests", Queen's University Economics Department Working Paper No. 122\%, pp. 1-17

13. Mohd Isa Mohd Yaziz, Yap Voon Choong and David Yong Gun Fie, "Loan Loss Provisioning Practices" Journal of Modern Accounting and Auditing, June 2013, Vol. 9, No. 6, pp. 814-822

14. Yao, Jun and Oppewap Harmen (2016), "Unit pricing matters more when consumers are under time pressure", European Journal of Marketing, Vol. 50, Iss. 5/6, pp. 1094-1114 


\section{Appendix}

Table 1. Definition of variables

\begin{tabular}{|c|c|}
\hline Variables & Glossary \\
\hline Consumer Price Index (CPI) & $\begin{array}{l}\text { A single/fixed basket of goods and services which represents the consumption } \\
\text { basket of all households with year } 2010 \text { as a base year, and their respective } \\
\text { weights }(2010=100) \text { are as follows: } \\
\text { Food non-alcoholic beverages } 30.2 \\
\text { Alcoholic beverages, tobacco } 2.9 \\
\text { Clothing \& footwear } 3.3 \\
\text { Housing, water, gas \& electricity } 23.8 \\
\text { Furnishing \& household equipments } 3.8 \\
\text { Health } 1.7 \\
\text { Transport } 13.7 \\
\text { Communication } 5.2 \\
\text { Recreation services \& culture } 4.9 \\
\text { Education } 1.1 \\
\text { Restaurant \& Hotel } 2.9 \\
\text { Miscellaneous goods \& services } 6.5\end{array}$ \\
\hline Non-Performing Loans (NPL) & Commercial banks and Islamic banks Non-Performing Loans \\
\hline
\end{tabular}

Table 2. CPI Inflation by States and Income Groups in 2015 (Annual change, \%)

\begin{tabular}{|c|c|c|c|}
\hline & & Total & \\
\hline MALAYSIA & \multicolumn{2}{|l|}{2.1} & \multirow{15}{*}{ Inflation tends to be higher for more urbanised states } \\
\hline \multirow[t]{5}{*}{ Highly urbanised states } & Kuala Lumpur & 2.78 & \\
\hline & Selangor \& Putrajaya & 2.34 & \\
\hline & Pulau Pinang & 2.45 & \\
\hline & Melaka & 1.92 & \\
\hline & Johor & 2.78 & \\
\hline \multirow{4}{*}{ Semi-urbanised states } & Negeri Sembilan & 2.30 & \\
\hline & Perak & 1.77 & \\
\hline & Kedah \& Perlis & 1.65 & \\
\hline & Terengganu & 1.85 & \\
\hline \multirow[t]{4}{*}{ Less-urbanised } & Sabah \& Labuan & 0.88 & \\
\hline & Sarawak & 1.45 & \\
\hline & Pahang & 1.83 & \\
\hline & Kelantan & 1.91 & \\
\hline \multicolumn{3}{|c|}{ Inflation tends to be higher for lower income groups } & \\
\hline
\end{tabular}
Source: Source: Bank Negara Malaysia (2016), Annual Report 2015 "Box Article: Inflation and the Cost of Living", pp. 67 